\title{
Kvote 2-optagelse og akademiske præstationer: Hvor stor betydning har det adgangsgivende eksamenssnit?
}

Lotte Dyhrberg O'Neill, kiropraktor, MMedEd, ph.d., adjunkt, Center for Medicinsk Uddannelse, Aarhus Universitet og Enheden for Uddannelsesudvikling, Syddansk Universitet.

Maria Cecilie Vonsild, cand.scient., AC-fuldmagtig, Enheden for Uddannelsesudvikling, Syddansk Universitet.

Birgitta Wallstedt, cand.scient., leder af SDU Universitetspaedagogik, Syddansk Universitet.

\section{Reviewet artikel}

Kvote 2-optagelse (optagelsesprøver) til medicinstudiet har vist sig at have virket beskyttende på tidligt studiefrafald sammenlignet med kvote 1-optagelse på Syddansk Universitet. Dette prospektive kohortestudie af de samme kohorter viser, at de lavere adgangsgivende karakterer i kvote 2-gruppen samtidigt kun var forbundet med lidt lavere bachelorkaraktergennemsnit.

\section{Introduktion}

Det adgangsgivende eksamenssnit fra en gymnasial eksamen er - og har længe været - den vigtigste optagelsesparameter til videregående uddannelse i Danmark generelt. På medicinstudierne i Danmark optages pt. 50-90\% af de medicinstuderende på kvote 1, dvs. på baggrund af den adgangsgivende eksamens karakterer. Både dansk og udenlandsk forskning viser, at adgangsgivende karakterer er en prædiktor for akademiske præstationer i form af opnåede karakterer under medicinstudiet (Christensen \& Juul, 1999; Ferguson et al., 2002). Ferguson et al.'s metaanalyse fra 2002 viste også, at et adgangsgivende karaktersnit fra forudgående uddannelse er den bedste prædiktor for karakterer under medicinstudiet, som vi kender til, og at den var en 'god omend ikke perfekt prædiktor'.

På Syddansk universitet (SDU) optog man i årene 2002-2007 imidlertid omtrent halvdelen af de medicinstuderende på andre parametre end højeste karakterer (eksperimentel kvote 2-optagelse). Og det viste sig, at de, der blev optaget på kvote 1, faktisk havde omkring 1,8 gange større relativ risiko $(\mathrm{OR}=1,8)$ for at falde fra inden for 2 år efter studiestart i forhold til de, der blev optaget via den eksperimentelle kvote 2-optagelse (O'Neill et al., 2011a). Kvote 2-optagelsen syntes altså at have haft en selvstændig beskyttende effekt i forhold til studiefrafald for disse kohorter på trods af, at kvote 2-erne som gruppe havde signifikant lavere adgangsgivende karakterer 
og dermed formodentlig var en anelse mindre akademisk egnede end kvote 1-erne, hvis vi ser isoleret på effektmålet karakterer på lægestudiet. Frafald/gennemførelse er uden tvivl et helt fundamentalt uddannelseseffektmål, som bør tages seriøst for alle interessenters skyld, dog er det ikke det eneste relevante i en samlet betragtning. Gennemførelse kan derfor ikke uden videre anskues isoleret og ukritisk som alene værende lig med det at 'klare sig bedre', selvom det selvfølgelig er den grundlæggende forudsætning. Den i studietiden opnåede faglighed (her målt som eksamensresultater) er også et vigtigt og selvstændigt uddannelseseffektmål. Herudover er de studerendes beståelsesfrekvens ved eksamenerne og deres studieprogressionshastigheder også relevante effektmål, der er med til at karakterisere den samlede akademiske præstation.

Formålet med dette studie var at undersøge sammenhængen mellem adgangsgivende karakterer og akademiske præstationer for medicinske bachelorer optaget på SDU i årene 2002-2007. Delmålene var: At præsentere modeller for bachelorkaraktergennemsnit samt at undersøge, om der var forskel på de to kvoters bachelorkaraktergennemsnit, beståelsesfrekvens og progressionshastighed.

\section{Metode}

Design

Studiedesignet var et prospektivt kohortestudie.

\section{Deltagere}

Populationen af interesse var de studerende som blev optaget på medicinstudiet på SDU mellem 2002-2007. Data om deltagerne blev indsamlet via det studieadministrative databasesystem (STADS) og en separat optagelsesdatabase for de studerende på sundhedsvidenskab samt, hvor nødvendigt, fra et papirarkiv af hhv. en statistiker på studiekontoret (databasedata) og en studentermedhjælper (arkivdata) i marts 2010. Statistikeren var ansvarlig for kvalitetssikring af de udtrukne data. Data fra SDU indeholdende studerendes CPR-nr. blev gemt på en CD af statistikeren og siden af forskerne sendt til Danmarks Statistik (DS) med anbefalet post primo maj 2010. Danmarks Statistik udtrak relevante data for en række sociale variable på baggrund af de studerendes CPR-nr. Herefter blev alle datasæt (SDU- og DS-data) anonymiseret og krypteret af DS, således at CPR-numrene blev fjernet, og deltagerne fik en unik personidentifikationskode tildelt i stedet. Forskerne kunne således kun se og anvende de anonymiserede data og havde ikke adgang til krypteringen. Alle data blev gjort tilgængelige for forskerne via en sikret web-adgang. Kun aggregerede data (statistisk output) og altså ikke rådata eller data der muliggør genkendelse (f.eks. pga. sjældenhed) må ekstraheres fra Danmarks Statistik. Forskerne overholdt DS's regler for dataekstraktion og havde ikke på noget tidspunkt i processen kendskab til deltagernes CPR-nr. eller identitet. Projektet var ikke anmeldelsespligtigt for Region Syddanmarks etiske komite. 


\section{Variable fra SDU}

Følgende variable blev udtrukket fra SDU: Kvote, alder, kohorte, adgangsgivende eksamenstype og -gennemsnit, køn, prioritet, overflytter, bachelorsnit, beståelsesfrekvens, progressionshastighed.

\section{Kvote}

Hvert år havde lægeuddannelsen på SDU ca. 1200-1700 ansøgere, hvor af ca. 150 blev optaget i kvote 1 . Af de resterende ansøgere blev ca. 300 årligt inviteret til optagelsesprøve på baggrund af motivation og kvalifikation, og af disse 300 blev ca. 150 årligt optaget i kvote 2. Populationen af medicinstuderende i dette studie er kodet som værende kvote 1- eller kvote 2-optagne. Kvote 1-ansøgere optaget udelukkende på baggrund af deres gennemsnit fra den adgangsgivende eksamen. Kvote 2-ansøgere skulle (som kvote 1-ansøgerne) opfylde et minimumskrav for karaktergennemsnit (8 på den gamle 13-skala) og de specifikke adgangskrav til bestemte niveauer i en række fag. Herefter foregik udvælgelsen i kvote 2 på baggrund af en sammensat testscore fra en optagelsesprøve bestående af fire elementer.

Vi har tidligere beskrevet administrationen, scoringen og reproducerbarheden af denne særlige kvote 2-optagelse på medicinstudiet (O'Neill 2011; O'Neill et al., 2009.), så vi nøjes derfor med en kortere beskrivelse her. Kvote 2-ansøgere blev bedt om at medsende en skriftlig 'motivation' med ansøgningen. Motivationen bestod af et essay, i hvilket ansøgerens skriftlige kommunikationsfærdigheder, refleksioner i forhold til tidligere livserfaringer, begrundelser for studievalg og tanker om fremtidig lægegerning blev vurderet. Hvert essay blev scoret af en videnskabelig/administrativ medarbejder eller en medicinstuderende og en score mellem 0-100 på en global rating scale blev givet. Herudover fik ansøgerne en kvalifikationsscore på baggrund af oplysningerne på ansøgningsskemaet fra Den koordinerede Tilmelding (KOT) samt den medsendte dokumentation herfor. Kvalifikationsscorer fra 0-100 point blev givet af en videnskabelig/administrativ medarbejder for relevans og kvantitet af: Tidligere erhvervserfaring, uddannelse, udenlandske udvekslingsophold e.l., frivilligt/organisationsarbejde og ledererfaring. De der sammenlagt klarede sig bedst på et vægtet gennemsnit af motivationen og kvalifikationen blev sidenhen inviteret til optagelsesprøve på SDU, som bestod af en almenvidenstest og et optagelsesinterview. Almenvidenstesten var en multiple choice-test bestående af 60 spørgsmål, som skulle besvares på 15 minutter. Formatet var 'one best answer'. Indholdet var meget bredt med mange subdomæner, f.eks.: biologi, fysik, kunst, gastronomi, musik, sundhed, politik, nyheder etc. Hensigten var at finde ansøgere med nysgerrighed og overskud nok til at interessere sig bredt for mange emner, idet man formodede, at sådanne karakteristika var vigtige for tilfredshed og gennemførelse. Denne almenvidenstest resulterede i en score på mellem $0-100 \%$ rigtige og selve scoringen foregik via elektronisk scanning af svarark. Efter multiple choice-testen deltog ansøgerne i et optagelsesinterview. Optagelsesinterviewet var semistruktureret og varede $25 \mathrm{mi}-$ 
nutter. Hensigten var at bedømme: Interessen for medicinstudiet og lægegerningen; forventninger til studiet, studielivet og professionen; modenhed i forhold til alder; sociale færdigheder; stresstolerance; empati og interviewadfærden generelt. Interviewet resulterede i en uafhængig score på mellem 0-100 på global rating scale fra henholdsvis en videnskabelig medarbejder (typisk en læge) og en medicinstuderende, og et gennemsnit heraf udgjorde således den endelige interviewscore. Den endelige optagelsesscore for kvote 2-optagelsen var et vægtet gennemsnit af hhv. kvalifikations-, almen videns- og interviewscorerne.

Alder

De studerendes studiestartsalder målt i år blev fundet ved at trække fødselsdatoen fra studiestartsdatoen.

Kohorte

Optagelseskohorten var året for optagelsen. Studerende optaget i optagelsesprojektperioden 2002-2007 er inkluderet i dette studie.

Eksamenstype

Den adgangsgivende eksamenstype blev kategoriseret i fire kategorier: Matematisk studentereksamen (mstx), sproglig studentereksamen (sstx), andre eksamenstyper eller dispensation (andet/disp.) og udenlandsk eksamen (udenlandsk).

Adgangsgivende karaktersnit

Adgangsgivende karaktersnit var gennemsnittet af karaktererne fra den adgangsgivende eksamen omregnet til 7-trinsskalaen.

Køn

De studerendes køn: Mand eller kvinde.

Prioritet

Studieprioriteten var den prioritet (1.-8.), som den studerende gav medicinstudiet på SDU på deres KOT ansøgningsskema.

Overflytter

Hvis den studerende tidligere havde været indskrevet på et studie på SDU, blev vedkommende kategoriseret som overflytter.

Bachelorsnit

Bachelorsnittet er gennemsnittet af samtlige karakterer (omregnet til 7-trinsskalaen), som blev tildelt de studerende fra optagelseskohorterne 2002-2007, der havde færdiggjort bachelorstudiet på Medicin i marts 2010.

\section{Beståfrekvens}

Beståfrekvensen er antallet af beståede eksamener divideret med antallet af eksamensforsøg per marts 2010. 


\section{Progressionshastighed}

Progressionshastigheden er det gennemsnitlige antal European Credit Transfer System (ECTS) points optjent per måned i løbet af den observerede tid (fra studiestart til marts 2010). Et fuldtidsstudieår udgør 60 ECTS, dvs. man burde have en gennemsnitlig progressionshastighed på 5 ECTS/måned, hvis man ingen studieforsinkelser har og mindre i tilfælde af forsinkelse.

\section{Variable fra Danmarks Statistik}

Følgende variable blev leveret af Danmarks Statistik: Lægeforælder, oprindelse, forældreskab, samboende forældre, forælder på ydelse, akademikerfar, akademikermor. Disse variable kunne selvsagt kun ekstraheres for medicinstuderende, som var danske statsborgere.

\section{Lageforælder}

Hvis de studerende havde $\geq 1$ forælder, som havde fuldført en medicinsk kandidatgrad, blev de kodet som havende en lægeforælder.

\section{Udviklingsland}

De studerende blev kategoriseret $\mathrm{i}$ to grupper, nemlig med oprindelse i enten et udviklet land eller et udviklingsland. Udviklede lande blev defineret af Danmarks Statistik som: Europa (bortset fra Tyrkiet, Cypern, Aserbajdsjan, Usbekistan, Kasakhstan, Kirgisistan, Georgien, Tadsjikistan og Armenien), Grønland, Nordamerika, Japan, New Zealand og Australien. Udviklingslande blev defineret som alle andre lande end de udviklede lande. Hvis den studerende selv eller den studerendes mor blev identificeret som værende indvandrer fra et udviklingsland, blev den studerende kategoriseret som havende oprindelse i et udviklingsland. Hvis den studerende ikke havde en mor, var det farens oprindelse der afgjorde oprindelseskategorien

\section{Forældreskab}

De studerende blev defineret som værende forældre hvis de havde $\geq 1$ barn med en fødselsdato, som lå før afslutningsdatoen for den medicinske bachelorgrad.

\section{Samboende forældre}

Hvis de studerende havde to biologiske forældre, som var registreret med samme adresse i optagelsesåret, blev de kategoriseret som havende samboende forældre. At have ikke-samboende, biologiske forældre kan skyldes f.eks. død og skilsmisse/separation eller andet.

\section{Forælder på ydelse}

Hvis de studerende blev identificeret som havende $\geq 1$ forælder på fuld indkomsterstattende ydelse i optagelsesåret (minimum 360 dage det år), blev de kategoriseret som havende en forælder på ydelse. 


\section{Akademikerfar/-mor}

Hvis den studerendes biologiske far/mor havde en universitetsgrad (bachelor, kandidat eller ph.d.-grad), blev den studerende kategoriseret som havende en akademikerfar/-mor.

Analyse

Beskrivelserne af alle variable både fra SDU og Danmarks Statistik blev gennemgået for at tjekke for forandringer i/uensartet dataindsamlingsmetode i løbet af perioden. Variablene blev enten blot klargjort til analyse (SDU-data) eller decideret genereret ved kobling af forskellige datasæt (sociale variable fra Danmarks Statistiks datasæt). Manglende data på de sociale variable (Danmarks Statistiks data) blev kategoriseret sammen med non-event/reference-gruppen og en oversigtstabel blev lavet. Alle parvise variabelkombinationer blev systematisk undersøgt for kollinearitet og tomme celler før analysen ved inspektion af matrixgraf-plots, $2 \times 2$-tabeller og box-plots. Individuelle prædiktorer af bachelorsnit blev identificeret ved univariate, lineære regressionsanalyser, og prædiktorer med $p<0,1$ blev inkluderet $i$ en multivariat model. Den multivariate model for det opnåede bachelorsnit på medicinstudiet fremkom ved en multivariat, lineær regressionsanalyse. Ved mutivariat analyse kan flere relevante, forklarende variable samtidigt bidrage med forklaringskraft i forhold til et multifaktorielt fænomen. Dermed opnår man mindre confounding og bias af koefficienter end ved at studere prædiktorerne enkeltvis (univariatanalyse). De præsenterede modeller blev undersøgt for opfyldelsen af de statistiske forudsætninger: Linearitet, proportionalitet, additivitet og distribution af residualer. Herudover blev indflydelsesrige datapunkter undersøgt med henblik på evt. begrundet eksklusion af skævvridende cases. Linearitet blev undersøgt ved inspektion af plots af residualerne mod hhv. predicted y samt de uafhængige variable. Proportionalitet blev undersøgt ved at specificere de kontinuerte uafhængige variable (alder og adgangsgivende karaktersnit) som kategoriske variable. Vi valgte kun at undersøge plausible interaktioner (additivitet), og vi fandt at en interaktion mellem den adgangsgivende eksamenstype og det adgangsgivende karaktersnits størrelse måske nok var mest oplagt for de præsenterede modeller. Residualernes fordeling blev undersøgt ved inspektion af histogrammer, p-norm og q-norm plots i STATA 11. Indflydelsesrige datapunkter blev tjekket ved inspektion af plots med leverage mod de standardiserede residualer. Samtlige analyser blev foretaget med STATA 11.

\section{Resultat}

Tabel 1 resumerer samtlige variable og angiver kategorier og kodning for hhv. danske/alle studerende optaget i årene 2002-2007. 
Tabel 1. Medicinstuderende optaget på Syddansk Universitet 2002-2007.

\begin{tabular}{|c|c|c|c|c|}
\hline & \multicolumn{2}{|c|}{ Kode } & \multicolumn{2}{|l|}{$\mathrm{N}$} \\
\hline & Alle & Danske & Alle & Danske \\
\hline Optagelses-kvote & & & 1544 & 1074 \\
\hline - $\quad$ Kvote 1 & 1 & 1 & 722 & 454 \\
\hline - $\quad$ Kvote 2 & 2 & 2 & 822 & 620 \\
\hline Alder(år) & - & - & 1544 & 1074 \\
\hline & & & $M=22,82$ & $M=22,88$ \\
\hline & & & SD 3,29 & SD 3,28 \\
\hline Kohorte & & & 1544 & 1074 \\
\hline - $\quad 2002$ & 1 & 1 & 233 & 159 \\
\hline $\begin{array}{l}-\quad 2003 \\
-1\end{array}$ & 2 & 2 & 255 & 164 \\
\hline - $\quad 2004$ & 3 & 3 & 271 & 192 \\
\hline $\begin{array}{l}-\quad 2005\end{array}$ & 4 & 4 & 252 & 181 \\
\hline$-\quad 2006$ & 5 & 5 & 260 & 170 \\
\hline $\begin{array}{l}-\quad 2007 \\
\end{array}$ & 6 & 6 & 273 & 208 \\
\hline Eksamen & & & 1544 & 1074 \\
\hline - $\quad$ Mstx & 1 & 1 & 751 & 739 \\
\hline - $\quad$ Sstx & 2 & 2 & 127 & 127 \\
\hline - $\quad$ Anden/dispensation & 3 & 3 & 199 & 186 \\
\hline - Udenlandsk & 4 & 3 & 467 & 22 \\
\hline Adgangsgivende karaktersnit & - & - & 1526 & 1067 \\
\hline & & & $\mathrm{M}=8,32$ & $M=8,12$ \\
\hline & & & SD 1,63 & SD 1,67 \\
\hline Køn & & & 1544 & 1074 \\
\hline - $\quad$ Mand & 0 & 0 & 578 & 425 \\
\hline - Kvinde & 1 & 1 & 966 & 649 \\
\hline Prioritet & & & 1544 & 1074 \\
\hline - $\quad$ Første prioritet & 1 & 1 & 917 & 706 \\
\hline - $\quad$ Ikke første prioritet & 2 & 2 & 627 & 368 \\
\hline Overflytter & & & 1544 & 1074 \\
\hline - $\quad$ Nej & 0 & 0 & 1402 & 945 \\
\hline$-\quad J a$ & 1 & 1 & 142 & 129 \\
\hline Læge forælder & & & & 1074 \\
\hline - $\quad$ Nej & & 0 & & 785 \\
\hline - $\quad$ Manglende data & - & 0 & - & 137 \\
\hline - $\quad \geq 1$ læge forælder & & 1 & & 152 \\
\hline Oprindelse & & & & 1074 \\
\hline - Udviklede lande & & 0 & & 959 \\
\hline - $\quad$ Manglende data & - & 0 & - & 17 \\
\hline - $\quad$ Udviklings-lande & & 1 & & 98 \\
\hline Forældreskab & & & & 1074 \\
\hline - $\quad$ Ingen børn & - & 0 & - & 1037 \\
\hline Forældreskab & & 1 & & 37 \\
\hline Samboende forældre & & & & 1074 \\
\hline - $\quad$ Nej & & 0 & & 231 \\
\hline - $\quad$ Manglende data & - & 0 & - & 132 \\
\hline - Ja & & 1 & & 711 \\
\hline Forældre på ydelse & & & & 1074 \\
\hline - Nej & - & 0 & - & 900 \\
\hline _ $\quad \geq 1$ forælder på ydelse & & 1 & & 174 \\
\hline Akademiker far & & & & 1074 \\
\hline - $\quad$ Nej & & 0 & & 672 \\
\hline - $\quad$ Manglende data & - & 0 & - & 116 \\
\hline $\mathrm{Ja}$ & & 1 & & 286 \\
\hline Akademiker mor & & & & 1074 \\
\hline - $\quad$ Nej & & 0 & & 883 \\
\hline - $\quad$ Manglende data & - & 0 & - & 64 \\
\hline - Ja & & 1 & & 127 \\
\hline Bachelorsnit & - & - & 970 & - \\
\hline & & & $\mathrm{M}=6,83$ & \\
\hline & & & $\mathrm{SD}=1,73$ & \\
\hline Bestå-frekvens & & & 1528 & - \\
\hline & & & $\mathrm{M}=88,81$ & \\
\hline & & & $S D=19,07$ & \\
\hline Progressionshastighed & & & $\begin{array}{r}1544 \\
\mathrm{M}=3,98 \\
\mathrm{SD}=1,40\end{array}$ & - \\
\hline
\end{tabular}

$N=$ antal personer observeret, $M=$ gennemsnitsverdien, og $S D=$ standardafoigelsen. 


\section{Modeller for bachelorgennemsnit}

Tabel 2 viser resultatet af regressionsanalyserne for det opnåede bachelorsnit for samtlige studerende (dvs. danske og udenlandske), som havde erhvervet sig en bachelor i Medicin per marts 2010. Det adgangsgivende karaktersnit som univariat prædiktor kunne forklare 8,23\% af variansen i bachelorkaraktersnit. De studerendes køn, deres studieprioritet og, om de tidligere havde været indskrevet på et studie på SDU, havde ingen signifikant effekt på bachelorsnittet. Alle variable som opfyldte kravene til specifikation i den multivariable model (alder, optagelseskohorte, eksamenstype og adgangsgivende karaktersnit) var signifikante, uafhængige prædiktorer af bachelorsnittet. Højere alder ved optagelse, matematisk studentereksamen (mstx) og højere adgangsgivende karaktersnit var således forbundet med et højere bachelorsnit. For to studerende med en karakters forskel i adgangsgivende snit på 7-skalaen kunne man således forvente en karakterforskel på 0,357 i bachelorsnittet (se $\mathrm{b}$ for det adgangsgivende karaktersnit i den multivariate model i tabel 2). Den i tabel 2 præsenterede model kunne $i$ alt forklare $13 \%$ af variansen i bachelorsnit $\left(R^{2}=0,130\right)$.

Tabel 2. Model for bachelorkaraktergennemsnit på medicin ved SDU for optagelseskohorterne 20022007 pr. marts $2010(n=970)$.

\begin{tabular}{|c|c|c|c|c|c|c|}
\hline & \multicolumn{3}{|c|}{$\begin{array}{c}\text { Univariate } \\
\text { anayser }\end{array}$} & \multicolumn{3}{|c|}{$\begin{array}{c}\text { Multivariat } \\
\text { Model }\end{array}$} \\
\hline & $\mathrm{b}$ & $\mathrm{KI}_{95 \%}$ & $\mathrm{p}$ & $\mathrm{b}$ & $\mathrm{KI}_{95 \%}$ & $\mathrm{p}$ \\
\hline Alder & $-0,063$ & $-0,103 ;-0,023$ & 0,002 & 0,046 & 0,$002 ; 0,090$ & 0,042 \\
\hline Kohorte & & & $0,000^{a}$ & & & $0,000^{\mathrm{a}}$ \\
\hline$-\quad 2003$ & 0,227 & $-0,114 ; 0,567$ & 0,191 & 0,169 & $-0,148 ; 0,485$ & 0,295 \\
\hline - 2004 & 0,107 & $-0,223 ; 0,438$ & 0,524 & 0,014 & $-0,306 ; 0,335$ & 0,930 \\
\hline$-\quad 2005$ & 0,602 & 0,$254 ; 0,951$ & 0,001 & 0,404 & 0,$048 ; 0,760$ & 0,026 \\
\hline-2006 & 0,846 & 0,$495 ; 1,198$ & 0,000 & 0,601 & 0,$260 ; 0,942$ & 0,001 \\
\hline $\begin{array}{l}-\quad 2007 \\
\end{array}$ & $-1,226$ & $-3,171 ; 0,719$ & 0,216 & $-1,403$ & $-1,985 ;-0,821$ & 0,000 \\
\hline Eksamen & & & $0,003^{a}$ & & & $0,000^{\mathrm{a}}$ \\
\hline - Sstx & $-0,478$ & $-0,879 ;-0,076$ & 0,020 & $-0,495$ & $-0,897 ;-0,094$ & 0,016 \\
\hline - Andet/disp. & $-0,653$ & $-1,050 ;-0,255$ & 0,001 & $-0,945$ & $-1,361 ;-0,528$ & 0,000 \\
\hline - Udenlandsk & $-0,076$ & $-0,322 ;-0,171$ & 0,546 & $-0,339$ & $-0,581 ;-0,096$ & 0,006 \\
\hline Adg. karaktersnit & 0,319 & 0,$252 ; 0,386$ & 0,000 & 0,357 & 0,$280 ; 0,434$ & 0,000 \\
\hline Kvinde & 0,187 & $-0,038 ; 0,411$ & 0,103 & - & - & - \\
\hline Ikke første prioritet & $-0,113$ & $-0,335 ; 0,108$ & 0,315 & - & - & - \\
\hline Overflytter fra SDU & 0,115 & $-0,252 ; 0,481$ & 0,539 & - & - & - \\
\hline \multicolumn{4}{|l|}{ Konstant } & 2,865 & 1,$516 ; 4,214$ & 0,000 \\
\hline \multicolumn{4}{|l|}{ Nobs } & \multicolumn{3}{|c|}{961} \\
\hline \multicolumn{4}{|l|}{$\mathrm{R}^{2}$} & \multicolumn{3}{|c|}{0,130} \\
\hline
\end{tabular}

$b=$ den estimerede hældnings koefficient, KI95\% $=95 \%$ konfidensinterval for $b, p=p$-værdien. Adg. karaktersnit=adgangsgivende karaktersnit. Nobs=antal personer $i$ analysen. $R^{2}=$ andelen af den totale varians som modellen kan forklare. Referencekategorier er: 2002- kohorten, mstx, mand, forste prioritet, ikke overflytter fra SDU. B-koefficienterne for kategorierne herover er således udregnet i forhold til disse referencekategorier.

${ }^{a} p$-værdien for den samlede variabel (kohorteleksamen) 
I tabel 3 præsenteres de tilsvarende analyser, dog udelukkende for de danske studerende. I tabel 3 har vi derfor også kunnet inkludere og kontrollere for de sociale variable (Danmarks Statistik-data) som potentielle prædiktorer for bachelorsnittet. Det adgangsgivende karaktersnit som univariat prædiktor kunne forklare 10,1\% af variansen i bachelorkaraktersnit for gruppen af danske studerende. Igen viste alder, optagelseskohorte, eksamenstype og adgangsgivende karaktersnit sig at være signifikante uafhængige prædiktorer af bachelorsnittet i den multivariable model. Af de specificerede sociale variable i den multivariate model (udviklingsland, samboende forældre, akademikermor) overlevede kun udviklingsland som en signifikant uafhængig prædiktor af bachelorsnittet (tabel 3). Studerende med dansk nationalitet, der enten selv var indvandrere eller efterkommere af indvandrere fra et udviklingsland, havde som gruppe et bachelorsnit der i gennemsnit var 0,732 lavere end gruppen af studerende med oprindelse i udviklede lande (tabel 3). Den multivariate model i tabel 3 for de danske studerende som altså også inkluderede sociale variable kunne samlet forklare $17,3 \%$ af variansen i bachelorsnittet.

Tabel 3. Model for bachelor-karaktergennemsnit på medicin ved SDU for optagelseskohorterne 20022007 pr. marts $2010(n=970)$.

\begin{tabular}{|c|c|c|c|c|c|c|}
\hline & \multicolumn{3}{|c|}{$\begin{array}{c}\text { Univariate } \\
\text { anayser }\end{array}$} & \multicolumn{3}{|c|}{$\begin{array}{c}\text { Multivariat } \\
\text { model }\end{array}$} \\
\hline & $\mathrm{b}$ & $\mathrm{KI}_{95 \%}$ & $\mathrm{p}$ & $\mathrm{b}$ & $\mathrm{KI}_{95 \%}$ & $\mathrm{p}$ \\
\hline Alder & $-0,052$ & $-0,100 ;-0,005$ & 0,031 & 0,070 & 0,$0171 ; 0,123$ & 0,010 \\
\hline Kohorte & & & $0,009^{a}$ & & & $0,000^{\mathrm{a}}$ \\
\hline$-\quad 2003$ & 0,339 & $-0,077 ; 0,755$ & 0,110 & 0,254 & $-0,100 ; 0,608$ & 0,159 \\
\hline$-\quad 2004$ & 0,131 & $-0,267 ; 0,529$ & 0,518 & 0,007 & $-0,352 ; 0,367$ & 0,969 \\
\hline$-\quad 2005$ & 0,611 & 0,$193 ; 1,030$ & 0,004 & 0,397 & 0,$004 ; 0,791$ & 0,048 \\
\hline$-\quad 2006$ & 0,671 & 0,$238 ; 1.103$ & 0,002 & 0,476 & 0,$070 ; 0,882$ & 0,022 \\
\hline $\begin{array}{l}-\quad 2007 \\
\end{array}$ & $-0,994$ & $-4,387 ; 2,399$ & 0,565 & $-1,694$ & $-2,168 ;-1,219$ & 0,000 \\
\hline Eksamen & & & & & & $0,000^{\mathrm{a}}$ \\
\hline -Sstx & $-0,498$ & $-0,901 ;-0,096$ & 0,015 & $-0,542$ & $-0,939 ;-0,145$ & 0,008 \\
\hline -Andet ${ }^{\mathrm{b}}$ & $-0,619$ & $-1,012 ;-0,227$ & 0,002 & $-0,895$ & $-1,327 ;-0,463$ & 0,000 \\
\hline Adg. karaktersnit & 0,351 & 0,$271 ; 0,430$ & 0,000 & 0,401 & 0,$307 ; 0,495$ & 0,000 \\
\hline Kvinde & 0,098 & $-0,171 ; 0,368$ & 0,474 & - & - & - \\
\hline Ikke første prioritet & $-0,261$ & $-0,539 ; 0,016$ & 0,065 & 0,018 & $-0,251 ; 0,287$ & 0,895 \\
\hline Overflytter & 0,270 & $-0,125 ; 0,666$ & 0,180 & - & - & - \\
\hline Læge forælder & $-0,159$ & $-0,507 ; 0,189$ & 0,370 & - & - & - \\
\hline Udviklingsland & $-0,730$ & $-1,177 ;-0,282$ & 0,001 & $-0,732$ & $-1,208 ;-0,257$ & 0,003 \\
\hline Forældreskab3 & $-0,351$ & $-0,920 ; 0,218$ & 0,226 & - & - & - \\
\hline Samboende forældre & 0,262 & $-0,027 ; 0,551$ & 0,075 & 0,149 & $-0,134 ; 0,432$ & 0,303 \\
\hline Forælder på ydelse & 0,141 & $-0,240 ; 0,522$ & 0,468 & - & - & - \\
\hline Akademiker far & 0,062 & $-0,226 ; 0,351$ & 0,671 & - & - & - \\
\hline Akademiker mor & 0,533 & 0,$129 ; 0,937$ & 0,010 & 0,257 & $-0,095 ; 0,608$ & 0,152 \\
\hline \multicolumn{4}{|l|}{ Nobs } & \multicolumn{3}{|c|}{664} \\
\hline $\mathrm{R}^{2}$ & & & & & 0,1728 & \\
\hline
\end{tabular}

$b=$ den estimerede hældnings koefficient, KI95\%=95\% konfidensinterval, $p=p$-værdien. Adg. karaktersnit=adgangsgivende karaktersnit. Reference-kategorier er: kvote 2, 2002 kohorten, mstx, mand, forste prioritet, ikke overflytter fra SDU, ingen lageforældre, oprindelse $i$ et udviklet land, ingen børn, ikkesamboende forældre, ingen forældre på ydelse, ingen akademikerfar, ingen akademikermor. B-koefficienterne for kategorierne herover er udregnet i forhold til disse referencekategorier.

a $p$-værdien for den samlede variabel (kohorte eller eksamen).

${ }^{b}$ Alle andre former for eksamen inkl. dispensationer og udenlandske eksamener. 
Undersøgelsen af de to modeller (tabel 2 \& 3) understøttede, at vi kunne tillade os at antage linearitet og proportionalitet. Vi fandt ingen signifikant interaktion mellem adgangsgivende eksamenstype og snittets størrelse, og må derfor antage additivitet. Additivitet betyder, at vi kan tillade os at summere (addere) effekterne af de individuelle, uafhængige prædiktorvariable i den samlede multivariate model for effektmålet. Residualerne var normalfordelte. Vi fandt ingen grund til fjernelse af indflydelsesrige datapunkter i nogen af modellerne, i alle tilfælde var de tilhørende standardiserede residualer tæt på 0 , så disse datapunkter udøvede snarere en god indflydelse på modellerne.

\section{Kvoternes bachelorkarakterer, beståelsesfrekvens og progressionshastighed}

Tabel 4 viser forskellene i adgangsgivende snit, bachelorsnit, beståfrekvens og progressionshastighed for de to optagelseskvoter. Kvote 1-bachelorer pr. marts 2010 havde et bachelorsnit, der gennemsnitligt var 0,58 karakterer højere end kvote 2bachelorerne, selv om de ved optagelsen havde et adgangsgivende snit, der var 2,4 karakterer højere (tabel 4). Der var ingen signifikant forskel i beståfrekvens og progressionshastighed mellem de to kvoter.

Tabel 4. Karakterer, beståfrekvens og progressionshastighed per kvote for medicinstuderende ved SDU fra optagelseskohorterne 2002-2007 pr. marts 2010.

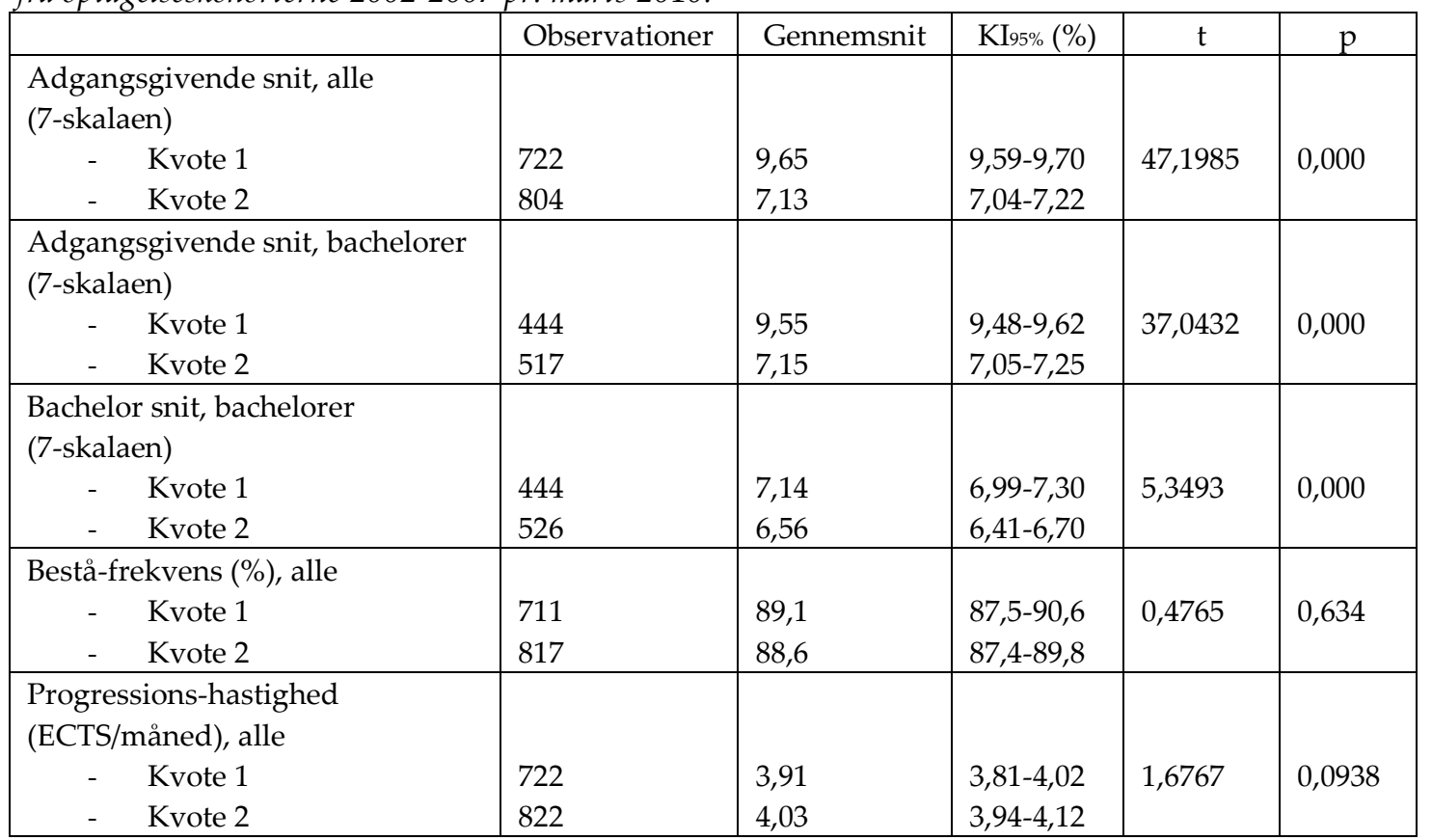

$K I_{95} \%=95 \%$ konfidens-intervallet, $t=t$-værdien og $p=p$-værdien. ECTS=European Credit Transfer System point.

\section{Diskussion}

Det adgangsgivende karaktersnit som univariat prædiktor kunne forklare hhv. 8,23\% og 10,1\% af variansen i bachelorkaraktersnit i de præsenterede modeller (tabel 2 \& 3 respektive). Alder, optagelseskohorte, adgangsgivende eksamenstype og adgangsgivende eksamens karaktersnit var signifikante uafhængige prædiktorer af bachelorsnittet i begge modeller (tabel 2 \& 3). Af de sociale variable var 'udviklingsland' den 
eneste signifikante variabel i en multivariat model (tabel 3). Kvote 1-erne havde som gruppe et bachelorsnit, der gennemsnitligt var 0,58 karakterer højere på 7-skalaen end kvote 2-erne, men der var ingen signifikant forskel på kvoternes beståfrekvens og progressionshastighed.

Ferguson et al.'s (2002) internationale metaanalyse viste at adgangsgivende karakterer kunne forklare ca. 9\% af variansen i opnåede karakterer på medicinstudiet. Til sammenligning fandt vi altså, at de adgangsgivende karakterer kunne forklare hhv. $8,23 \%$ af variansen i bachelorsnit for alle studerende og 10,1\% i bachelorsnit for undergruppen af danske studerende. Med andre ord, vores resultater for de adgangsgivende karakterers forklaringskraft i forhold til karakterer på medicinstudiet svarer altså ganske godt til resultaterne af de største internationale analyser. Ferguson et al. (2002) konkluderede at adgangsgivende karakterer - som univariat prædiktor - var en 'god men ikke perfekt prædiktor' for karakterer opnået på medicinstudiet, og det er fortsat den bedste prædiktor, vi kender til. I Danmark har Christensen \& Juul (1999) ligeledes også fundet en klar sammenhæng mellem karaktererne ved den adgangsgivende eksamen og kandidateksamen for medicinstuderende på Aarhus Universitet (Pearsons $\mathrm{r}=0,50 ; \mathrm{p}<0,001$ ). I vores studie gik adgangsgivende karakterer oven i købet styrket ud af de multivariate analyser med større koefficienter end i de univariate analyser (tabel $2 \& 3$ ). Til trods for alt dette kan man sige, at i praksis endte den gennemsnitlige karakterforskel mellem de to kvoter med at skrumpe ind med en faktor 4: Fra 2,4 på adgangstidspunktet til beskedne 0,58 karakterers forskel i bachelorsnit (tabel 4). Denne forskel svarer til kun 3,9\% (0,58/15) af den totale 7-trinsskala (fra -3 til 12). Man må således nok konkludere, at der var en pris at betale, omend ganske beskeden, i form af lidt lavere bachelorsnit ved at optage kvote 2-studerende med lavere adgangsgivende snit i dette tilfælde. Herudover var der ingen signifikant forskel på de to kvoters beståfrekvens og progressionshastighed (tabel 4), når vi ser på den samlede gruppe af optagne på data-udtrækstidspunktet (marts 2010). Tabel 4 indikerer dermed samlet set, at den akademiske egnethed i de to kvoter i praksis sandsynligvis ikke var så forskellig efter en årrække. Vi har heller ikke kunnet påvise øget social diversitet (bl.a. målt på forældres højest fuldførte uddannelsesniveau) blandt kvote 2-optagne i forhold til kvote 1-optagne (O'Neill et al., 2011b). Fordelene ved anvendelse af optagelsesprøver på medicin har dog i enkelte studier vist sig at være en beskyttelse mod frafald (O'Neill et al., 2011a; Reibnegger et al., 2011; Urlings-Strop et al., 2009), men der er sandsynligvis kun publiceret ganske få studier, som har undersøgt denne sammenhæng i det hele taget (O'Neill et al., 2011c), så en eksperimentel indstilling til og yderligere forskning i spørgsmålet om en frafaldsbeskyttende effekt af optagelsesprøver er selvfølgelig stadig påkrævet. Det er uvist hvorfor optagelsesprøver kunne tænkes at have en frafaldsbeskyttende effekt. Måske er de, der 'overlever' optagelsesprøver (eller et hvilket som helst forhindrings- eller udskillelsesløb), generelt mere motiverede. Hulsman et al. (2007) sammenlignede 
hollandske medicinstuderende optaget via tre forskellige optagelsesprocedurer: Optagelsesprøver, optagelseslotteri og karakterbaseret optagelse. De studerende optaget ved hjælp af optagelsesprøver var signifikant mere selvrapporteret motiverede end de øvrige studerende, alligevel var det den karakterbaserede optagelsesgruppe, der klarede sig bedst akademisk og udtrykte mindst behov for mere tid til selvstudier. Forfatterne påpegede muligheden for, at optagelsesproceduren kan have påvirket optagelsesprøvegruppens efterfølgende studiemotivation og professionelle identitetsdannelse særskilt positivt. Psykologen Øiestad (2007) påpeger, at vores motivation for en given opgave generelt kræver to helt fundamentale forudsætninger; nemlig at vi dels opfatter opgaven som værende meningsfyldt, men også at vi har tiltro til vores egen formåen og mulighed for succes (self-efficacy). Øget tiltro eller selfefficacy induceret af kvote 2-optagelsen, kunne have været forårsaget af bl.a.: Oplevelsen af at have gennemgået og mestret en udfordring som optagelsesprøverne (enactive mastery experience); oplevelsen af at have klaret sig relativt godt i forhold til det store flertal af ansøgere, som ikke blev optaget (vicarious experience); og oplevelsen af tiltro til egnethed og personlighed, som blev tildelt af vidende og troværdige bedømmere i optagelsesprocessen (verbal persuasion) (Bandura, 1997). Med andre ord: Det er muligt, at den teoretiske effekt (øget motivation) fortrinsvis blev induceret af selve den intervention, optagelsesprøverne udgjorde, og ikke nødvendigvis var et udtryk for et forudgående karaktertræk. Hvorom alting er: Adgangsgivende karakterer er altså - isoleret betragtet - stadig den bedste enkeltprædiktor for opnåede karakterer på medicinstudiet, selv om denne effekt ikke behøver at have særlig stor betydning for forskellen i kvoternes studiepræstationer i praksis (tabel 4), formentlig fordi andre faktorer (f.eks. alder, optagelseskohorte, gymnasial eksamenstype og etnicitet) også har indflydelse (tabel 2 \& 3). Herudover er det samtidigt muligt, at optagelsesprøver er forbundet med øget motivation (induceret eller ej) og måske deraf følgende øget fastholdelse i de tidlige studieår, men dette er endnu ikke undersøgt i tilstrækkeligt omfang (O'Neill et al., 2011a; Reibnegger et al., 2011; UrlingsStrop et al., 2009; Hulsman et al., 2007). Det er hypoteser, der selvfølgelig bør testes på flere forskellige uddannelser og institutioner. På SDU planlægger vi at fortsætte med at undersøge dette også på uddannelserne i Idræt og sundhed, Klinisk biomekanik og Psykologi.

\section{Begrænsninger}

Manglende specifikation af relevante, forklarende variable og misklassifikation af variable kan ikke udelukkes - begge dele kan give anledning til bias af resultater. Derudover kan manglende data for de sociale variable også resultere i bias. Vi undersøgte også en alternativ model for danskerne, hvor de manglende data fik deres egen kategori, men der var relativt ubetydelige forskelle i forhold til den i tabel 3 præsenterede model. Vi valgte at præsentere den simpleste model (tabel 3) for at lette overblikket. 


\section{Konklusion}

Adgangsgivende karakterer er stadig den bedste enkeltprædiktor for karakterer på medicinstudiet, som vi kender til, både i Danmark og internationalt. Det betyder at kvote 2-optagelse som involverer lavere adgangsgivende karakterer risikerer at være forbundet med lavere opnåede karakterer under studiet. Vores studie viser dog samtidigt at i praksis var der ringe/ingen forskel på kvoternes bachelorkarakterer, beståfrekvens og progressionshastighed for de undersøgte kohorter. Imidlertid er det muligt, at optagelsesprøver kan være forbundet med øget motivation og øget fastholdelse i de tidlige studieår. En eksperimentel indstilling til optagelsesprøver og den effekt, de har på frafald, gennemførselshastighed og karakterer er påkrævet ikke kun på medicinstudiet, men også på andre videregående uddannelser.

Lotte Dyhrberg O'Neill er adjunkt ved Center for Medicinsk Uddannelse, Aarhus Universitet og udlånt som pædagogisk medarbejder ved Enheden for Uddannelsesudvikling på Syddansk Universitet, hvor hun bl.a. tidligere har arbejde med kvote 2-optagelsen på kiropraktorstudiet og medicinstudiet. Forfatter til en række overvejende engelsksprogede artikler om optagelse og frafald.

Maria Cecilie Vonsild er AC-fuldmægtig ved Enheden for Uddannelsesudvikling for Det Sundhedsvidenskabelige Fakultetssekretariat på Syddansk Universitet, hvor hun bl.a. er projektleder for kvote 2optagelsesprøverne på idrætsstudiet, kiropraktorstudiet, psykologistudiet og medicinstudiet.

Birgitta Wallstedt er leder af SDU Universitetspæedagogik, Syddansk Universitet. Hun har været primus motor for implementering af kvote 2-optagelsesprøverne på Sundhedsvidenskab og har publiceret på dansk og engelsk om optagelse og frafald.

\section{Referencer}

Bandura, A. (1997). Self-efficacy. The exercise of control. New York: W. H. Freeman and Company.

Christensen, J., \& Juul, S. (1999). Adgangsgivende eksamens indflydelse på lægeuddannelsen. I: Ugeskrift for Læger 161(3), s. 257-262.

http://www.ugeskriftet.dk/lf/UFL/uf199 00/1999 2000/ufl9903/v_p/257.htm (tilgået 24.01.13).

Ferguson, E., James, D., \& Madeley, L. (2002). Factors associated with success in medical school: Systematic review of the literature. I: British Medical Journal 324(7343), s. 952-957.

http://www.bmj.com/highwire/filestream/349199/field highwire article pdf/0. pdf (tilgået 24.01.13).

Hulsman, R. L., van der Ende, J. S., Oort, F. J., Michels, R. P., Casteelen G., \& Griffioen, F. M. (2007). Effectiveness of selection in medical school admissions: evaluation of the outcomes among freshmen. I: Medical Education 41(4), s. 369377.

O'Neill, L. D. (2011). Admission tests in medical education. Generalizability, predictive validity and dropout. Ph.d.-afhandling. Odense: Syddansk Universitet.

O’Neill, L. D., Korsholm, L., Wallstedt, B., Eika, B., \& Hartvigsen, J. (2009). Generali- 
zability of a composite student selection programme. I: Medical Education 43(1), s. $58-65$.

O’Neill, L. D., Hartvigsen, J., Wallstedt, B., Korsholm, L., \& Eika, B. (2011a). Medical school dropout - testing at admission versus selection by highest grades as predictors. I: Medical Education 45(11), s. 1111-1120.

O'Neill, L. D., Vonsild, M., \& Wallstedt, B. (2011b). Could non-grade based selection improve medical student socio-demography diversity? I: Medical Education (in review).

O'Neill, L. D., Wallstedt, B., Eika, B., \& Hartvigsen, J. (2011c). Factors associated with dropout in medical education: a literature review. I: Medical Education 45(5), s. 440-454.

Reibnegger, G., Caluba, H. C., Ithaler, D., Manhal, S., Neges, H. M., \& Smolle, J. (2011). Dropout rates in medical students at one school before and after the installation of admission tests in Austria. I: Academic Medicine 86(8), s. 1040-1048.

Urlings-Strop, L. C., Stijnen, T., Themmen, A. P. N., \& Splinter, T. A. W. (2009). Selection of medical students: a controlled experiment. I: Medical Education 43(2), s. 175-183.

Øiestad, G. (2006). Feedback. København: Dansk Psykologisk Forlag. 